(C) 2013

Циновий О. В., кандидат біологічних наук

Інститут тваринництва НААН

\title{
ВПЛИВ ДЕЗІНФЕКТАНТІВ НА КЛІНІКО-БІОХІМІЧНІ ТА ГЕМАТОЛОГІЧНІ ПОКАЗНИКИ КУРЧАТ-БРОЙЛЕРІВ
}

\section{Рецензент - кандидат біологічних наук $\Theta$. М. Білецький}

Встановлено, щуо за використання препаратів «Неохлор» у концентрації $1 \%$ із розрахунку $0,04 \mathrm{n} / \mathrm{s}^{3}$ та «Максисан» концентрації 0,05-0,1\% із розрахунку 0,02-0,04 $\mathrm{\pi} / \mathrm{m}^{3}$ із метою дезінфекиії приміщень не впливають негативно на напруженість гуморального імунітету, клініко-біохімічні та гематологічні показники курчат-бройлерів. Результати бактеріологічних, біохімічних, гематологічних $i$ серологічних досліджень курчат-бройлерів протягом шести тижнів вирощування дають підставу рекомендувати обидва препарати для впровадження у птахівничі господарства.

Ключові слова: дезінфекиія, препарати "Неохлор», «Максисан», птахівничі приміщення, імунітет, курчата.

Постановка проблеми. Для сучасного промислового птахівництва характерна висока концентрація птиці на відносно обмежених територіях, поточна система вирощування, збільшення щільності посадки у пташниках, що призводить до репродукції мікроорганізмів у високих концентраціях та посилення їх патогенних властивостей.

Аналіз основних досліджень і публікацій, у яких започатковано розв'язання проблеми. За таких умов необхідна добре продумана і чітко спланована система профілактичних заходів, спрямованих на зменшення мікробного «тиску», поскільки саме він впливає на мікробну забрудненість повітря у пташниках, що негативно діє на ріст і розвиток птиці, іiі збереженість та продуктивність [3].

У період вирощування та утримання птиці для зменшення мікробного «тиску» в пташниках проводиться дезінфекція за наявності в ній птиці [1-4]. У зв'язку з незначною кількістю вітчизняних дезінфікуючих засобів, що застосовуються, виникає необхідність у розробці та впровадженні нових дезпрепаратів, які за своїми бактерицидними властивостями й нетоксичністю переважали б існуючі $[5,6]$.

Мета досліджень. Метою досліджень було вивчення ефективності використання дезінфікуючих препаратів «Неохлор» та «Максисан» для дезінфекції птахівничих приміщень за наявності птиці.

Основним завданням дослідження було ви- вчення впливу дезінфікуючих препаратів «Неохлор» та «Максисан» на мікробний «тиск» у приміщенні, де вирощувалася птиця, клінікобіохімічні показники крові та на напруженість гуморального імунітету у щеплених курчат.

Методика проведення досліджень. Дослідження проводили на курчатах-бройлерах кросу «Гібро ПГ» у кількості 200 голів.

«Неохлор» - препарат, який у своєму складі містить гіпохлорит натрію - 5,0 - 9,0 \% за активним хлором та допоміжні речовини - антикорозійні, миючі, ароматизуючі, а також компоненти для стабілізації активного хлору; виготовлений ЗАТ «Український науково-виробничий центр проблем дезінфекції».

«Максисан» - рідкий концентрат світлосолом'яного кольору, активно діючою речовиною якого $є$ комплекс шести четвертинних амонієвих сполук; виготовлений ЗАТ «Український науково-виробничий центр проблем дезінфекції».

Вакцини: проти інфекційної бурсальної хвороби (ІБХ) із штаму «ХГ» (Росія), вакцина проти ньюкаслської хвороби (НХ) фірми НВП «БіоТест-Лабораторія» (Україна).

Курчат-бройлерів щепили: проти ІБХ двічі - у 12- та 24-денному віці; проти НХ одноразово - у 20-денному віці.

Курчатам усіх груп із 7-го до 42-го дня життя 3 профілактичною метою у корм вводили кокцидіостатик «Байкокс» (Німеччина) з розрахунку 5,0 г на 10 кг корму.

Вивчення бактерицидної дії препарату проводили шляхом змивів із різних тест-об'єктів площею $10 \mathrm{~cm}^{2}$ у пробірки зі стерильним фізіологічним розчином: у контрольній групі - 1 раз на добу, в дослідній двічі - до та після обробки дезінфектантами.

Матеріал висівали на чашки Петрі з МПА i ставили у термостат на 24 години. Після цього підраховували кількість колоній.

Змиви з окремих тест-об'єктів розводили у 10 і 100 разів.

Концентрацію мікроорганізмів у повітрі вивчали за загальноприйнятим методом седимента- 


\section{ВЕТЕРИНАРНА МЕДИЦИНА}

ції за експозиції 5 хвилин. У контрольній групі дослідження проводили 1 раз на добу, а в дослідній до та після обробки дезінфектантами.

Через 24 години підраховували колонії на МПА.

Кількість еритроцитів, рівень гемоглобіну та ШОЕ визначали в 30- та 40-денному віці за загальноприйнятими методами.

Напруженість імунітету до ІБХ визначали у 40-добовому віці методом імуноферментного аналізу (ІФА) (набір виробництва ВНДІЗТ, м. Владимир), до НХ у реакції затримки гемаглютинації (РЗГА).

Біохімічні дослідження проводили у 30 - і 40добовому віці з використанням наборів фірми «Філісіт» (Україна.)

Визначали у сироватці крові: активність аспартатамінотрасферази (АсAT) за методом Райтмана та Френкеля (1957р.), лужної фосфатази - за методом Кінда (1954 р), загальний білок - біуретовим методом, сіромукоїди - турбодіметричним методом.

Технологічні параметри вирощування курчатбройлерів (щільність посадки, температурний режим, освітлення, повітрообмін) були витримані згідно з рекомендаціями фірми.

Для проведення досліджень було сформовано чотири групи птиці - по дві групи на кожний дезпрепарат - дослідну і контрольну групи, по 50 голів у кожній.

Препарати «Неохлор» та «Максисан» застосовували за наявності птиці аерозольним методом за допомогою генератора «Ураган».

Результати досліджень. У процесі проведення бактеріологічних досліджень встановлено, що аерозольна обробка препаратами «Неохлор» та «Максисан» сприяє зменшенню кількості мікроорганізмів.

У середньому бактерицидна дія препарату «Неохлор» на твердих поверхнях становила $95,4 \%$, у повітрі - $55 \%$.

Бактерицидна дія препарату «Максисан» на твердих поверхнях становила, у середньому, $85,4 \%$, у повітрі - 40-50\%.

У контрольних групах, де не було використано дезінфектантів, кількість мікроорганізмів постійно зростала.

Так, із 20-го по 34-й день вирощування кількість їх збільшувалася в 10 разів у повітрі, а на твердих тест-об'єктах - у 20-400 разів.

Після використання препарату «Неохлор» біохімічними дослідженнями сироваток крові нами встановлено, що кількість сіромукоїдів у дослід- ній групі курчат була більшою, ніж у курчат контрольної групи.

Це вказує на підвищення загальної резистентності птиці.

За використання препарату «Максисан» цей показник був однаковий як у дослідній, так i контрольній групах.

Щодо інших показників (ферментативної активності сироватки крові, аспартатамінотрансферази (АсАТ), лужної фосфатази, кількості білку) у разі використання препаратів «Неохлор» та «Максисану» отримані результати були подібні, що вказує на відсутність негативного впливу препаратів на вуглеводний, ліпідний, мінеральний та білковий обміни.

Після використання обох препаратів гематологічними дослідженнями було визначено підвищення рівня гемоглобіну і кількості еритроцитів у першому дослідженні у 30-денному віці й стабілізацію рівня цих показників за повторного дослідження у 40-денному віці в дослідних групах, у порівнянні з контрольними.

Відмічено зменшення показників ШОЕ (за використання «Неохлору») у курчат у 30- та 40денному віці в дослідних групах, порівняно 3 контрольними. I, ймовірно, не змінювався цей показник за використання препарату «Максисан».

Зміни цих показників свідчать про покращання функціонального стану птиці та оздоровлюючий ефект препарату (табл. 1, 2).

Вплив дезінфектантів «Неохлору» та «Максисану» на сероконверсію в разі щеплення курчатбройлерів проти ІБХ та НХ вивчали у порівнянні 3 контролем.

Дослідження проводили за методом РЗГА (НХ) та ІФА (ІБХ).

Напруженість імунітету до двох інфекцій (ІБХ, НХ) вивчали у курчат 40-денного віку (табл. 3, 4).

Напруженість імунітету до НX у курчатбройлерів як дослідної, так і контрольної груп, становила $100 \%$.

Напруженість імунітету до ІБХ у контрольній групі була на 5 \% вищою порівняно $з$ дослідною - $95 \%$ і $90 \%$ відповідно.

Напруженість імунітету до ІБК у дослідній групі була вища, порівняно 3 контролем, але показники рівня імунітету як у дослідній, так і в контрольній групах були значно нижчі за норму (напруженість імунітету становила $55 \%$ та $50 \%$ відповідно). 
ВЕТЕРИНАРНА МЕДИЦИНА

\section{1. Біохімічні та гематологічні показники курчат-бройлерів за використання "Неохлору"}

\begin{tabular}{|l|c|c|c|c|}
\hline \multicolumn{1}{|c|}{$\begin{array}{c}\text { Назва показника, } \\
\text { од. вимірювання }\end{array}$} & \multicolumn{2}{c|}{$\begin{array}{c}\text { І група, } \\
\text { контрольна }\end{array}$} & \multicolumn{2}{c|}{$\begin{array}{c}\text { II група, } \\
\text { дослідна }\end{array}$} \\
\hline Вік птиці, дні & 30 днів & 40 днів & 30 днів & 40 днів \\
\hline Загальний білок, г/л & $38,52 \pm 0,59$ & $34,49 \pm 0,82$ & $36,20 \pm 1,25$ & $37,25 \pm 1,09$ \\
\hline АсАТ, мкмоль/год*мл & $1,55 \pm 0,09$ & $1,63 \pm 0,03$ & $1,51 \pm 0,03$ & $1,62 \pm 0,03$ \\
\hline Лужна фосфатаза, нмоль/с*л & $11290 \pm 2575,02$ & $5416 \pm 72,1$ & $5330 \pm 435,03$ & $4748 \pm 362$ \\
\hline Сіромукоїди, помутніння, од. & $2,75 \pm 0,04$ & $2,84 \pm 0,11$ & $3,04 \pm 0,18$ & $3,24 \pm 0,19$ \\
\hline Гемоглобін, г/л & $131,18 \pm 4,92$ & $130,92 \pm 5,28$ & $143,94 \pm 4,31$ & $135,60 \pm 2,46$ \\
\hline Еритроцити, млн & $3,61 \pm 0,41$ & $3,41 \pm 0,25$ & $3,83 \pm 0,24$ & $3,40 \pm 0,35$ \\
\hline ШОЕ, мм/год & $3,8 \pm 0,74$ & $3,6 \pm 0,45$ & $2,4 \pm 0,45$ & $2,7 \pm 0,29$ \\
\hline
\end{tabular}

2. Біохімічні та гематологічні показники курчат-бройлерів за використання «Максисану»

\begin{tabular}{|l|c|c|c|c|}
\hline \multicolumn{1}{|c|}{$\begin{array}{c}\text { Назва показника, } \\
\text { од. вимірювання }\end{array}$} & \multicolumn{2}{|c|}{ І група } & \multicolumn{2}{c|}{ II група } \\
\hline \multicolumn{1}{|c|}{ Вік птиці, дні } & 30 днів & 40 днів & 30 днів & 40 днів \\
\hline Загальний білок, г/л & $38,52 \pm 0,59$ & $34,49 \pm 0,82$ & $32,58 \pm 1,59$ & $39,5 \pm 0,89^{*}$ \\
\hline АсАТ, мкмоль/год*мл & $1,55 \pm 0,09$ & $1,63 \pm 0,03$ & $1,66 \pm 0,09$ & $1,66 \pm 0,12$ \\
\hline Лужна фосфатаза, нмоль/с*л & $11290 \pm 2575$ & $5416 \pm 721$ & $110270 \pm 4062$ & $6572 \pm 671$ \\
\hline Сіромукоїди, од. помутніння & $2,75 \pm 0,04$ & $2,84 \pm 0,11$ & $2,70 \pm 0,20$ & $2,76 \pm 0,16$ \\
\hline Гемоглобін, г/л & $131,18 \pm 4,92$ & $130,92 \pm 5,28$ & $151,18 \pm 17,53$ & $136,60 \pm 5,08$ \\
\hline Еритроцити, млн & $3,61 \pm 0,41$ & $3,41 \pm 0,25$ & $3,18 \pm 0,30$ & $2,71 \pm 0,26$ \\
\hline ШОЕ, мм/год & $3,8 \pm 0,7$ & $3,6 \pm 0,4$ & $6,2 \pm 1,6$ & $3,2 \pm 0,5$ \\
\hline
\end{tabular}

3. Напруженість імунітету (\%) у курчат (препарат «Неохлор»)

\begin{tabular}{|c|c|c|c|}
\hline $\begin{array}{c}\text { № } \\
\text { групи }\end{array}$ & Кількість проб & НХ (РЗГА) & ІБХ (ІФА) \\
\hline 1 & 20 & 100 & 95 \\
\hline 2 & 20 & 100 & 85 \\
\hline
\end{tabular}

4. Напруженість імунітету (\%) у курчат (препарат «Максисан»)

\begin{tabular}{|c|c|c|c|c|}
\hline $\begin{array}{c}\text { № } \\
\text { групи }\end{array}$ & $\begin{array}{c}\text { Кількість } \\
\text { проб }\end{array}$ & НХ (РЗГА) & ІБХ (ІФА) & ІБК (ІФА) \\
\hline 1 & 20 & 100 & 95 & 50 \\
\hline 2 & 20 & 100 & 90 & 55 \\
\hline
\end{tabular}

\section{Висновки:}

1. За використання препаратів «Неохлор» $\mathrm{i}$ «Максисан» знижується мікробний «тиск» у приміщенні за наявності птиці. Бактерицидна активність препарату на твердих поверхнях у середньому становила 90,4 \%, у повітрі - $50 \%$.

2. Не відмічено негативного впливу препаратів «Неохлор» та «Максисан» на напруженість гуморального імунітету проти ньюкаслської хвороби та інфекційної бурсальної хвороби, а також

\section{БІБЛІОГРАФІЯ}

1. Байдевлятов Ю. А. Современные проблемы санации и дезинфекции в птицеводстве / Ю. А. Байдевлятов // Збірник матеріалів Міжнародної наук.-прак. конф., 4-6 квітня 2000 року. - на клініко-біохімічні та гематологічні показники птиці.

3. Результати бактеріологічних, біохімічних, гематологічних і серологічних досліджень курчат-бройлерів протягом шести тижнів вирощування дають підставу рекомендувати обидва препарати для дезінфекції приміщень за наявності в них птиці: для «Неохлору» - в концентрації $1 \%$ із розрахунку $0,04 \pi / \mathrm{m}^{3}$, для «Максисану» $0,05-0,1 \%$ із розрахунку $0,02-0,04 \pi / \mathrm{m}^{3}$.

K., 2000. - C. 12-14.

2. Байдевлятов Ю. А. Забруднення повітря пташників у процесі їх експлуатації / Байдевлятов Ю. А. // Ветеринарна медицина України. - 


\section{ВЕТЕРИНАРНА МЕДИЦИНА}

2001. - №10. - С. 29.

3. Дуюнов E. E. Застосування нових режимів дезінфекції для зменшення мікробної забрудненості повітря при вирощуванні бройлерів / Е. Е. Дуюнов // Птахівництво: Міжвід. тематич. наук. зб. / ІП УААН. - Харків, 2006. - Вип. 58. C. 3 .

4. Закомырдин А. А. Санация воздуха животиноводческих помещений / А. А Закомырдин, А. А. Поляков // Руководство по ветсанации. - М., 1986. C. 86-96.
5. Каратеев A. Н. Новый дезинфектант широкого спектра действия / А. Н. Каратеев, Н. И. Сахацкий, И. Ю. Безрукавая // Птахівництво: Міжвід. тематич. наук. зб./ ІП УААН. - Х., 2003. - Вип. 53. - C. 572-576.

6. Сахаикий И. Н. Дезинфицирующие средства для птицеводства: сравнительная эффективность (обзор) / И. Н. Сахацкий // Птахівництво: Міжвід. тематич. наук. зб. // ІП УААН. - Х., 2004. - Вип. 55. - C. 559-569. 